\title{
КУ
}

DOI: https://doi.org/10.32839/2304-5809/2021-9-97-10

УДК 379.82

Дубровіна I.B., Дерда К.I.

Національний педагогічний університет імені М.П. Драгоманова

\section{ІГРОВЕ ДОЗВІЛЛЯ В УКРАЇНІ ЯК НАПРЯМ ФОЛЬКЛОРНОЇ АТРИБУЦІї У ФОНДАХ НБУВ}

\begin{abstract}
Анотація. У статті досліджено історичні передумови розвитку ігрового дозвілля в Україні, яке відроджує традиційну обрядовість, відображає основи життедіяльності селянства та духовних цінностей народної календарної звичаєвості. Окреслено проблематику вітчизняного ігрового дозвілля як напрям фольклорної атрибуції, що має багатовікову спадщину. Календарні звичаї і обряди українців фрормально узгоджувалися з річним літургійним циклом православної церкви, головними віхами якого були так звані дванадесяті свята і пости. Доведено, що високохудожні елементи календарних звичаїв знаходять своє сучасне життя у творчості професійних і самодіяльних артистів, використовуються у декоративно-прикладному і театральному мистецтві, продовжують існувати у повір'ях та особистих ставленнях людей як зразок історичної пам'яті народу.
\end{abstract}

Ключові слова: ігрове дозвілля, культурно-освітня діяльність, звичаї та традиції минулого, культурнопросвітні форми дозвілля, рекреація, фрольклорна атрибуція.

Dubrovina Iryna, Derda Kateryna National Pedagogical Dragomanov University

\section{GAME LEISURE IN UKRAINE AS A DIRECTION OF FOLKLORE ATTRIBUTION IN NBUV FUNDS}

Summary. The article examines the historical preconditions of the Ukraine gaming leisure development, which revives the traditional ritualism, reflects the foundations of life of the peasantry and the spiritual values of the folk calendar customs. The issue of domestic gaming leisure as a direction of folklore attribution, which has a centuries-old heritage, is outlined. The calendar customs and rituals of Ukrainians were formally coordinated with the annual liturgical cycle of the Orthodox Church, the main milestones of which were the so-called twelfth holidays and fasts. It has been proved that highly artistic elements of the calendar customs find their modern life in the works of the professional and amateur performers, are used in arts and crafts and theatrical art, continue to exist in the beliefs and personal attitudes of people as a model of historical memory of a nation. Scientific research of the origins of gaming leisure in Ukraine opens the new ways to study the historical origins of the layer of national culture in the field of universal morality, humanism, values and virtues of the past. Understanding historical basis of the folk traditions, the factors that mediated them will facilitate the revival of Ukrainian culture, on the example of the funds of the National Library of Ukraine named after V.I. Vernadskyi. The role of the playgrounds in organization of entertainment, competitions with songs, dances is outlined. This proves the opinion that leisure performed a health-improving and relaxing function of the population of the past. The various playgrounds were primarily related to how the seasons changed: in the fall, the evening games to choose a couple and get married were organized; in winter there was the holiday of Kalyta and Maiden\&apos;s destiny, then Christmas and New Year divinations, carols, Christmas carols, winter greetings; in spring - spring-Easter games, and in summer - Green Holidays and Kupala. During the game leisure, our ancestors glorified the Sun, the forces of nature and paid homage to the dead, to whom we addressed and prayed and believed in their influence on the future life.

Keywords: game leisure, cultural and educational activity, customs and traditions of the past, cultural and educational forms of leisure, recreation, folklore attribution.

Постановка проблеми. У результаті жит-

11 тя і побуту мільйонів людей протягом віків в Україні сформувалося ігрове дозвілля, яке шліфувалося і варіювалося досвідом багатьох поколінь. В іграх, як у дзеркалі дивовижних уявлень наших предків, відображаються звичаї нашого народу, їхній побут та уявлення про світ [10, с. 140]. Кожна гра та забава мае свої специфічні фрункції та розвивае фізичні та моральні якості дітей. На жаль, за останні роки багато народних перлин було розгублено і забуто. Тому сьогодні мистецтвознавцям, культурологам потрібно по крупиці збирати безцінний скарб, щоб скласти в ціле мозаїку різноманітних ігор (рухові ігри, забави зі співом, приказки і примовки, рухові ігри та забави для розвитку сили, швидкісно-силових навиків та ін.) [9, с. 5]. I це можна зробити за умови розгляду глибинних процесів складного історичного шляху становлення ігрового дозвілля як атрибуції фольклору, в першу чергу, для роботи з населенням.

Аналіз останніх досліджень та публікацій. Науково-дослідницька та методична робота з питань дозвілля проводилась нами за такими напрямами: розробка категоріально-понятійного апарату; збирання, систематизація, аналіз історії та практики культурно-дозвіллевої діяльності; вивчення проблем організації дозвілля через вивчення фольклорознавства таких вчених, як: О. Боряк, В. Гусева, О. Дея, М. Гордійчука, 
М. Максимовича, О. Маслова, А. Метлинського Ф. Колесси, І. Квасниця. К. Квітки, Т. Косміної, А. Пономарьова, О. Правдюк, О. Пчілки, Л. Українки, М. Цертелєва та ін.

Виділення нерозв'язаних раніше частин проблеми. Українське ігрове дозвілля відроджує традиційну обрядовість, відображає основи життедіяльності селянства та духовних цінностей народної календарної звичаєвості, підтримуе позитивні народні звичаї та традиції, що не могло не позначитися на загальній екології культури та обрядотворчому русі. Це потребує серйозного науково-фрольклористичного, психолого-педагогічного дослідження, історичного окреслення проблематики в сучасному інформаційному соціумі [8, с. 97].

Мета статті - окреслити проблематику ігрового дозвілля в Україні як напрям фольклорної атрибуції, відслідувати історичний шлях розвитку та його особливості в Україні через опис свят хліборобського року, звичаїв та традицій, старовинних обрядів.

Виклад основного матеріалу. Як зберегти і передати усі ті кращі надбання національної культури, що були виплекані протягом століть українським народом? Певно через створення атмосфери дослідження національного спадку, життєдайного джерела народної мудрості. Збіднення ритуалізованої сорери життя - дозвілля, зачіпає головне - систему міжпоколінних зв'язків, котра $є$ основою нації та всього національного життя [5, с. 71]. Адже традиційна етнокультурна інформація може зберігатися тільки передаючись від прабатьків до онуків. Звернення до традиції, осмислення ігрового дозвілля дозволить пізнати витоки своєї культури та історії, зрозуміти сьогодення, уявити майбутне. «Той, хто не знає свого минулого, не варти майбутнього»: писав видатний шанувальник українознавства M. Рильський. Сьогоднішній час потребуе переосмислення ролі і місця ігрового дозвілля в просторі фольклорної атрибуції для упорядкування спектру народного досвіду та народної творчості.

Поняття «ігрове дозвілля» розуміемо як складову систему фольклорної атрибуції через її тісні зв'язки 3 хліборобським роком та призму народного світосприймання. Адже логіка народної культури була пов'язана 3 тим, що життевий цикл людини будувався за певним народним календарем обрядовості та сезонністю певних видів господарської діяльності [6, с. 200]. Пріоритет свят та обрядів формував культуру українців протягом календарного року [2, с. 46].

Своїм корінням українські ігри сягають в доісторичні, ще язичницькі, часи. Тоді наші предки жили в тісних зв'язках 3 природою і їх господарські заняття та світогляд єдналися 3 явищами природи. Вони щиро вірили, що є такі боги, які правлять світом і особливо шанували тих, від кого надіялись добра і щастя. Разом з цим гра була складовою частиною великого магічного ритуалу, що мав на меті вплинути на явища природи і життя. Уславлення божеств піснями. Танцями та іграми мало під собою практичну основу: задобрити оточуючу природу, щоб задобрити оточуючу природу i таким чином забезпечити собі достаток і благополуччя. 3 часом обрядові дійства наших предків втратили своє ритуальне значення і від них лишилась тільки молодіжні та дитячі забави. Ігри постійно передавались від старшого покоління до молодшого. Кожне покоління додавало щось нове, придумувало нові забави. Колективна народна мудрість породила багато різноманітних ігор, виховне значення яких важко переоцінити. Природні умови, історичні та економічні особливості розвитку тіеї чи іншої частини України наклали свій відбиток на народні ігри [7, с. 300].

Народно-календарні ігри були різними у дівчат і хлопців. Так, більш бурхливі та рухливі вони у хлопців, спокійніші в дівчат. Зеленосвятські дні були пов'язані із водінням хороводів та літніх ігор-забав, плетінням вінку та пусканням вінків на воду. На Масницю під час кулачних боїв був звичай витрясати млинці один 3 одного. Тому хлопці показували перед лицем старотців кулачні бої, силу роду, перестрибування через вогонь, воду, метання лука [4, с. 3].

У 1902 році видатному українському композитору Миколі Лисенку була присвячена збірка «Українські пісні з нотами» (укладач А. Конощенко). Автор зазначає про важливу роль варіативності українських народних пісень, їх оригінальності та мелодизми, які стануть у пригоді людям, які полюбляють фрольклор. Серед 100 пісень багато цікавих та варіативних, як: «Вилітали орли», «Рубате тополю», «По під терном стежечка» та ін. [3, с. 157].

Яскраво представлено у Національній бібліотеці України імені B.I. Вернадського свята та обряди Охтирського району з матеріалів фольклорної експедиції. Важливу роль у громадському житті традиційного українського села відігравала церква. Відвідання церкви вважалось релігійним і моральним обов'язком кожного християнина. За цим ревно стежили представники духовенства. Проте вони ж самі відзначали, що в народі ходили не стільки до церкви, скільки «під церкву», щоб поспілкуватись, похвалитись обновою, почути останні новини. На великі релігійні свята (Великдень, Різдво, Водохрещу, Храм та ін.) у церкві й біля неї (на цвинтарі) відбувалися загальногромадські ритуальні церемонії, масові народні розваги. Значне пожвавлення у життя селян вносили базари та ярмарки. На них вибирались не лише заради купівлі-продажу, а й для того, щоб відпочити від щоденних турбот, набратися нових вражень. Тут виступали циркачі, фокусники, мандрівні актори, співаки й танцюристи, сліпі кобзарі та лірники, петрушечники й вертепники, шарманщики, астрологи i фракіри. Повертаючись 3 ярмарку, селяни неодмінно купували гостинці та подарунки рідним, особливо дітям. Протягом віків в українському селі складався узвичаєний порядок соціалізації особи - прилучення 前 до життевих норм і цінностей коллективу та разом 3 цим - господарсько-побутова відособленість чоловіків і жінок. Досягнувши повноліття, молодь об'єднувалась у самостійні парубочі і дівочі громади. Вони мали свої специфрічні звичаї і традиції й комплектувалися за територіальним принципом. Несела мали одну парубочу громаду, а великі - кілька, що формувались в окремих частинах села. Вступаючи до громади, новачок мав частувати все товариство пивом або горілкою. На Поділлі ця 
церемонія називалась коронуванням і проходила як справжне обрядове дійство. У кожній парубочій громаді раз на рік обирали ватажка (старшого парубка, отамана, березу). Його обов'язки полягали в тому, щоб боронити інтереси парубоцтва перед сільською владою, керувати організацією молодіжних розваг, святкових ритуалів, наймати музик тощо. Менш чітко простежуеться організаційна структура дівочих громад, які на кінець XIX ст. майже повсюдно злилися з парубочими. Улітку молодь вечорами збиралась у людних місцях на розваги і танці (вулиці, колодки, пляс), а в холодний час - у спеціально найнятих хатах на вечорниці (досвітки, супрядки, годенки). Ця своерідна форма дозвілля молоді передбачала певний церемоніал відносин між парубками і дівчатами. Існувала певна ієрархія, згідно з якою у центрі майданчика танцювали старші парубки, а на периферії - молодші. За неписаними правилами дівчина не могла відмовитись від танцю, навіть якщо парубок їй не подобався. Якщо вона відмовлялась - їі могли вигнати з танщів на ігрищах. Ігрища - місця, де проводилися масові ігри, забави, змагання 3 піснями, танцями. Молодь могла розкритися й дати вихід своїй енергії та веселощам. Адже відомо про важку щоденну пращю та робочі будні наших пращурів. Тобто дозвілля виконувало оздоровчу та релаксуючу фрнкцію населення минулого [1, с. 169]. Різноманітні ігрища були пов'язані в першу чергу з тим, як відбувалася зміна пір року: восени організовували вечорничні ігри, пов'язані з вибором пари та одруженням; взимку було свято Калити та Дівочої долі, потім різдвяні та новорічні гадання, колядки, щедрівки, зимові вітання; навесні - весняно-великодні ігри, а улітку - Зелені свята й Купала. Наші пращури під час проведення ігрового дозвілля славили Сонце, сили природи та віддавали шану покійникам, до яких зверталися й молилися та вірили в їхній вплив на подальше життя.

Ігрища були неодмінною складовою богослужіння язичників, обов'язковою їх складовою було ïx проведення після жертвоприношень. I чільну роль відігравали тут скоморохи, які були головними організаторами дозвілля, артистами-виконавцями пісень та таночків на князівських святах. Любили стародавні українці відпочивати у скорочищі - місці, де в давні часи відбувалися свята, ритуали з танцями й «плесканням у долоні». За народними уявленнями, обов'язковим атрибутом ігрового дійства були пантоміми форми магічного танцю води, землі, вогню, які гарантували добробут та багатство в господі [2, с. 91]. Побутова релігія народних мас являла собою складну суміш християнських ідей з язичницькими віруваннями та уявленнями. До числа інститутів, породжених релігійними уявленнями й аграрним укладом побуту належали календарні свята і обряди, що регламентували всі сфрери життя українського селянина - виробничу, громадську, сімейну. У річному коловороті хлібороб спостерігав певну закономірність, усвідомлення якої вело його до виділення періодів річного циклу, що повторювались. Виробничі календарні цикли утворювались із послідовних дат праці у полі та вдома і супроводжувались релігійними святами і обрядами, магічними діями, забобон- ними прикметами, повір'ями, звичаями, багато 3 яких походили від первісної міри в залежність людини від надприродних сил. Календарні звичаї і обряди українців формально узгоджувалися з річним літургійним циклом православної церкви, головними віхами якого були так звані дванадесяті свята і пости [1, с. 169].

В аграрному календарі українців не було різкого розмежування між сезонами. Кожен із них плавно переходив у наступний, утворюючи нескінченний ряд кругооберту природи, чергування періодів праці й відпочинку. Найсприятливішим для селянського дозвілля вважався осінньо-зимовий період, особливо насичений різноманітними звичаями та обрядами [1, с. 169].

Дуже багатим $є$ репертуар традиційних великодніх ігор, представлений у фондах НБУВ, що поділялись на дитячі, парубочі, дівочі, змішані й загальні. Можемо знайти інформацію, що грунтовно описуеться звичаю ритуальних великодніх вогнів, які розкладали на пагорбах чи безпосередньо біля церкви у ніч із суботи на неділю [3, с. 158]. Підготовкою великого колективного багаття, яке мало горіти всю ніч, зазвичай займалась парубоча молодь. У деяких карпатських селах хлопці змагались між собою, намагаючись розкласти вогонь якомога вище в горах [2, с. 93].

Все село, від малого до великого, сходилося на масове великоднє гуляння, яке відбувалось на подвір'ї коло церкви. У Західній Україні й Поділлі ці гуляння називались гаївками, ягілками (від місцевої назви весняних пісень і хороводів). Протягом трьох великодніх днів усім парафіянам дозволялось дзвонити у церковні дзвони, яким приписувалась ритуально-магічна роль. Апогеєм аграрно-господарського року українського селянина було свято обжинок, багате обрядодійствами і піснями. Один із його компонентів - звичай спасової бороди, яку зав'язували з останніх пучечків незжатого колосся й лишали на хлібній ниві. Дослідники правомірно вбачають у цьому звичаї рештки жертвоприношення матері-землі. 3 останнього колосся жниці робили також гарний сніп і вінок, який, причепуривши квітами і стрічками, одягали найкрасивішій дівчині. 3 традиційними побажаннями господарям пердавали символічний сніп і вінок. У відповідь господар запрошував всіх до святкового столу. Звершувалося свято обжинковими піснями та іграми, хороводами. Обжинковий вінок зберігався в коморі до весни, саме 3 нього починали сівбу, що символізувало коло оберт календарно-обрядового року.

Сучасне ігрове дозвілля змінилося, але доповненням до новорічних свят стали дещо переосмислені традищійні календарні пісні українського народу колядки та щедрівки (переважно у сільській місцевості) стали надбанням етносу країни. Трансдрормоване свято Весни (або проводи Зими) увібрало в себе чимало рис давньої слов'янської Масляної. Розважальну частину свята складають народні ігри та звичаї, загадки, дражнили та прислів'я. Дуже часто використовуються у святах та обрядах дітей та молоді елементи обрядової традиції, такі як спалення опудала Зими, рядження, календарні пісні-веснянки, театралізовані сценки. Поступово відроджувалися вечорнищі як один із варіантів організації святкового дозвілля у роботі культур- 
но-освітніх закладів, у підготовці розважальних радіо- і телепрограм.

Сьогодні для дітей та молоді купальський вогонь, вода, рослини стали поетичними символами, а нічна квітка папороті, яка розпускаеться один раз в рік, перегукуеться з казковими образами літературних творів письменників: Л. Українки, I. Франка та ін. Сучасне «свято врожаю» включає традиційні хліборобські атрибути, як обжинковий сніп та вінок, пшеничний коровай тощо. Високохудожні елементи календарних звичаїв знаходять своє сучасне життя у творчості профресійних і самодіяльних артистів, використовуються у декоративно-прикладному і театральному мистецтві, продовжують існувати у повірях та особистих ставленнях людей як зразок історичної пам'яті народу.

Широко представлена в НБУВ фольклорна атрибуція, а саме: збірники Лемківського (у записах Ярослава Полянського), Подільського, Волинського, Охтирського (Слобожанщина), Буковинського, Київського фрольклор, мелодії з Поділля та Холмщини (зібрані П. Плосайкевичом і Я. Сенчиком), описи різних обрядів, зокрема хрестин, родин, весілля та похорони (за експедицією П. Чубинського).

Справжнім артефрактом фольклору є народні пісні з Південного Підкарпаття (укл. Ф. Колесса) за 1923 рік у книг печатні Юлія Фелдешія в Ужгороді. У цій збірці підкреслена особливість хороводних ігор, які взяли основу з вигукуванням повторюваних беззвязних слів, приспівок і коротких фрраз під такт примітивної танкової мелодії. Тому дуже важливими є синерктизм поєднання танку, музики та поезії.

У сучасній пресі вийшов цікавий для читачів збірник «Грайлик», що є прикладом унікального збірника народних пісень, дитям вертепів, загадок i скоромовок. Репертуар представляе не тільки реальну живу традицію, але й презентує багаторічну практичну діяльність M.I. Пилипчак та чолі фольклорного ансамблю «Цвітень». В основу репертуару колективу, який був утворений 1986 році, лягли експедищійні записи Марії та Василя Пилипчаків у різних регіонах України. Добре, що читачі можуть долучитися до розмаїття дитячих ігрових форм, записаних i розшифрованих автором. Також тут зустрічаються і рідкісні тексти, які свідчать про високу культурну модель життя наших пращурів.

Також під час екскурсії фондами НБУВ, читачі можуть ознайомиться 3 унікальними записами українських народних пісень, зроблені Лесею
Українкою та ㄲï сестрою Ольгою Косач в с. Колодяжне на Волині у 90-х роках XIX століття. Вони $\epsilon$ цінним першоджерельним матеріалом для історії українського фольклору і фрольклористики, для глибшого проникнення в творчу лабораторію Лесі Українки.

У книзі «Пісенний світ українознавства» (упорядник В. Коротя-Ковальська) здійснено спробу доторкнутися до цілісного і різноманітного світу ігрового дозвілля українського народу, його інтересів, ментальності, світогляду, естетичних ідеалів та критеріїв родинності, розуміти ті чи інші культурні явища, які відбуваються в сучасному суспільстві $[6$, с. 150].

На думку, В. Корот-Ковальської, основи духовності наших предків були непорушним законом життя, а обрядодійство вважалося священним, бо образність і символіка було написаним письмом [6, с. 150]. У збірці є пісні, які надруковано вперше у записах видатного педагога і фольклориста Василя Верховинця. Цікаво, що до кожного твору подано маленький опис, щоб народнопісенна творчість стала ближчою для усвідомлення та розуміння. Адже спадкоємність народних традицій починалася $з$ опанування фольклорними скарбами, сприйняття світу через образну кодову систему, прилучення до його обрядів, уявлень, вірувань.

Висновки та подальші перспективи. Отже, наукове обгрунтування вітчизняного ігрового дозвілля як фрольклорної атрибуції у фрондах НБУВ відкриває нові шляхи дослідження історичних витоків пласту вітчизняної культури на терені загальнолюдської моралі, гуманізму, цінностей та чеснот минулого. Вивчаючи «перлини кольору, народні ігри» дослідники мають змогу звернуться до нового бачення народних традицій, чинників що їх опосередкували. Адже відродження старовинної культури $є$ ознакою пріоритетності наукового суспільства знань. Подальших досліджень потребує рубрика «Ггрове дозвілля дітей» у фононах Нащіональної бібліотеки України імені В. I. Вернадського з експертизи вітчизняного та європейського фольклору. В умовах складаної пандемі та потреби у сощіалізації людини переглядається роль ігрового дозвілля для організації вільного часу населення, а тому підтримується ідея створення різноманітних культурно-просвітніх фрорм оздоровлення та відновлення емоційного стану людини. Історичне підгрунтя з вивчення дозвіллевої діяльності потребуе інтеграції нових арт-проектів, які б розкрили нові сторінки у рубриці «Ігрове дозвілля» НБУВ та були б цікавими для наукових досліджень.

\section{Список літератури:}

1. Богуш А., Лисенко Н. Українське народознавство в дошкільному закладі : навч. посібник. Київ : Вища шк., 1994. C. $169-187$.

2. Войтович В. Українська міфологія. Київ : Либідь, 2002. 664 с.

3. Культура і побут населення України : навч. посібник / укл. В. Наулко, Л. Артюх, В. Горленко та ін. Київ : Либідь, 1993. С. 157-173.

4. Літала сорока по зеленім гаю / уклад. В. Довжик. Київ, 1990. С. 3.

5. Петрова I. Становлення та розвиток педагогіки дозвілля в Україні у 20-ті роки XX ст. Piдна школа. 2005. № 4. C. $71-74$.

6. Пісенний світ українознавства (Зібрник народних, календарно-обрядових та авторських пісень для дітей та дорослих) / упорядник В. Коротя-Ковальська. Камянець-Подільський : ПП «Медобори-2006», 2011. 272 с.

7. Правдюк О. Українська музична фольклористика. Київ : Наукова думка, 1978. 323 с.

8. Скуратівський В. Берегиня. Київ, 1987. С. 97-98.

9. Українська минувшина: ілюстрований етнографічний довідник. 2-3 вид. / А.П. Пономарьов, Л.А. Артюх, Т.В. Косміна та ін. Київ : Либідь, 1994. 256 с. 
10. Українці: народні вірування, повіря, демонологія / упоряд., прим. та біогр. Нариси А.П. Пономарьова, Т.В. Косміної, О.О. Боряк. 2-е вид. Київ : Либідь, 1991. 640 с.

\section{References:}

1. Bohush A., Lysenko N. (1994) Ukrainske narodoznavstvo v doshkilnomu zakladi: navch.posibnyk [Ukrainian ethnography in preschool: textbook manual]. Kyiv: Vyshcha shk.

2. Voitovych V. (2002) Ukrainska mifolohiia [Ukrainian mythology]. Kyiv: Lybid.

3. Naulko V.I., Artiukh L.F., Horlenko V.F. ta in. (1993) Kultura i pobut naselennia Ukrainy: navch. posibnyk [Culture and life of the population of Ukraine: textbook manual]. Kyiv: Lybid.

4. Dovzhyk V. (1990) Litala soroka po zelenim haiu [Forty flew across the green grove]. Kyiv.

5. Petrova I. (2005) Stanovlennia ta rozvytok pedahohiky dozvillia v Ukraini u 20-ti roky XX st. [Formation and development of leisure pedagogy in Ukraine in the 1920s]. Ridna shkola, 4, 71-74.

6. Korotia-Kovalska V.P. (2011) Pisennyi svit ukrainoznavstva [Song world of Ukrainian studies]. Zibrnyknarodnykh, kalendarno-obriadovykh ta avtorskykh pisen dlia ditei ta doroslykh. Kamianets-Podilskyi: PP «Medobory-2006».

7. Pravdiuk O. (1978) Ukrainska muzychna folklorystyka [Ukrainian musical folklore]. Kyiv: Naukova dumka.

8. Skurativskyi V. (1987) Berehynia [Bereginya]. Kyiv.

9. Ponomarov A.P., Artiukh L.A., Kosmina T.V. ta in. (1994) Ukrainska mynuvshyna: iliustrovanyi etnohrafichnyi dovidnyk [Ukrainian past: illustrated ethnographic guide]. Kyiv: Lybid.

10. Ponomarova A.P., Kosminoi T.V., Boriak O.O. (1991) Ukraintsi: narodni viruvannia, poviria, demonolohiia [Ukrainians: folk beliefs, beliefs, demonology]. Kyiv: Lybid. 